\title{
WHAT MAKES MILLENNIALS HAPPY IN THEIR WORKPLACE?
}

\author{
Wai Meng Yap ${ }^{1^{*}}$ and Siti Khadijah Zainal Badri \\ ${ }^{1}$ Department of Psychology, HELP University, Persiaran Cakerawala, \\ Subang Bestari, 40150 Shah Alam, Selangor, Malaysia \\ ${ }^{2}$ Division of Organisational and Applied Psychology, Business School, \\ Faculty of Arts and Social Science, The University of Nottingham Malaysia Campus, \\ Jalan Broga, 43500 Semenyih, Selangor, Malaysia \\ *Corresponding author: WaiMeng.Yap@help.edu.my
}

Published online: 30 June 2020

To cite this article: Yap, W.M., \& Badri, S.K.Z. (2020). What makes millennials happy in their workplace? Asian Academy of Management Journal, 25(1), 103-121. https://doi.org/10.21315/aamj2020.25.1.6

To link to this article: https://doi.org/10.21315/aamj2020.25.1.6

\begin{abstract}
Happiness in the workplace remains to be an under-researched field which is unfortunate considering that the happiness-productive worker link has been strongly established. More essentially, there has been a lack of research on happiness in the workplace which considers a specific sample of millennials. In preparation for a workforce dominated with millennials, this research will help address the gap with regards to the lack of research on Malaysian millennials' happiness in the workplace. Through a thorough literature review, six predictors or antecedents of happiness in the workplace among millennials which are meaningful work, work autonomy, transformational leadership, workplace friendship, work life balance, and gratitude have been chosen in this research. This study consists of millennials ("millennials" or Generation $Y$ is defined in the selected literature as individuals born between years 1982 and 2004) who have undergone full time employment of at least one year or more. The results indicated that all the six predictors showed significant moderate to high positive relationships with happiness in the workplace. Multiple regression analysis showed that all six predictors significantly predicts millennials' happiness in the workplace, besides gratitude. Implications of this study with regards to managing millennial talent in organisations are then discussed.
\end{abstract}

Keywords: workplace happiness, well-being, millennials, workforce, work-life balance

(C) Asian Academy of Management and Penerbit Universiti Sains Malaysia, 2020. This work is licensed under the terms of the Creative Commons Attribution (CC BY) (http://creativecommons. org/licenses/by/4.0/). 


\section{INTRODUCTION}

Although happiness in general is being widely researched most commonly in association with life satisfaction (Joshanloo et al., 2016), happiness in the workplace remains to be underrepresented. Many constructs have been used and tested with regards to research on happiness in the workplace (Fisher, 2010). These constructs vary based on: (1) levels in which they are seen to exist; (2) constancy with time; and (3) the specific content (Fisher, 2010). For instance, the transient level or better known as person level construct seeks to understand the differences in mood of an employee in comparison to others, while unit level construct seeks an understanding of happiness in bigger units and groups of people (Fisher, 2010). Among some examples on constructs measuring happiness in the workplace are job satisfaction (Brief, 1998), organisational commitment (Stride et al., 2008), engagement (Harter et al., 2002), flow and intrinsic motivation (Salanova et al., 2006), and affect at work (Baas et al., 2008). Clearly, there are many constructs that have some association with happiness at work and they are vastly segregated into either measuring affect such as flow and intrinsic motivation or cognition which is focused on appraisals such as organisational commitment.

\section{Millennials as Background of Study}

Millennials or also known as the Generation $\mathrm{Y}$ are those who were born between 1982 and 2004 (Howe \& Strauss, 2009). Millennials are different from prior generations in terms of value and behaviours especially at work (Deal et al., 2010). Existing research has pointed out that the older generation of baby boomers in particular, viewed millennials as tough to communicate with, entitled, have weak communicative abilities, and naive (Deal et al., 2011; Hira, 2007; Myers \& Sadaghiani, 2010). There are also some that perceived millennials as impatient and disloyal, but ambitious and highly driven by personal values at work (Jacobson, 2007).

However, research which investigated happiness in the workplace among a sample of millennials has been minimal to none. As noted by Deal et al. (2010), researches published on millennials are not conclusive and often contradictory and in fact, perceptions on millennials are often rooted on urban myths and stereotypes. Thus, it is essential to explore the motivations in work among millennials and how it contributes to their happiness as much research has shown that their working styles and needs are unique from past generations (Hershatter \& Epstein, 2010). With approximately 2 billion millennials in the world today and by 2020 , they are expected to constitute over one third of the global workforce (ManpowerGroup, 2016) and by $2025,75 \%$ of the entire workforce (Deloitte, 2014). This research 
is essential to understand what makes millennials happy in the workplace, in preparation for a workforce dominated by millennials.

\section{LITERATURE REVIEW}

\section{Organisation and Its Effect Towards Millennial Happiness}

Today's work environment is increasingly geared towards flexible work approaches, technologic advancement, and decentralisation. All of these pose a great challenge for organisations to balance profit maximisation and implementation of supportive organisational structures in the face of such change (Allvin et al., 2011). Organisations which are not agile in the face of such change are said to create a psychological detachment between organisations and employees. Consequently, this form of detachment with weak identification of one's work then manifests itself through low levels of engagement and commitment among employees with organisations (Bakker et al., 2008). This notion is further supported by Gallup (2012) which has found that $86 \%$ of all employees in Germany reported lower to no work engagement with their organisations. This is of great concern as low employee commitment will then negatively affect the national economy (Gallup, 2012). Although there are many constructs surrounding happiness in the workplace, we conceptualise happiness in the workplace as affective well-being. This is consistent with Diener et al. (2019)'s conceptualisation which argues happiness as the presence of dispositional positive affect and absence of dispositional negative affect. Diener further stated that happiness is an essential and subjective experience and not from a third-party evaluation, as happiness or well-being is primarily in the mind of the subject (Diener, 2000). The benefits of operationally defining happiness in the workplace as affective well-being is further illustrated by Briner (1997). He states that affective well-being is multi-dimensional, and allows for the capturing of complexities, subtleties and changes which is crucial in the volatile nature of work experience. This in contrast with general and unidimensional measures might not capture the full nature of workplace variance. Further, Warr (1990) has also lent support for the use of affective well-being to measure happiness in the workplace, as affective well-being is said to be domain-specific which allows it to be used in relation to work domain constructs.

That said, this research serves as an exploratory platform in understanding millennials in the workplace. Further, as most organisational research does not focus on exploring happiness in the workplace using affective well-being as a dependent variable, this research is thus, of relevance. We chose a total of six predictors which were most relevant to be investigated with workplace happiness. 
The predictors are meaning at work, work autonomy, transformational leadership, workplace friendship, work-life balance, and gratitude. Sub-sections below will discuss further on the literature review for each specific predictor.

\section{Meaning at Work}

The importance of meaning at work is proven in a survey done by Kelly Services (2009) with a sample of 100,000 employees working in countries in the North America, Europe, and Asia Pacific region whereby approximately half of the respondents were willing to accept a lower pay in exchange for work that is deemed as meaningful. It is said that majority of people would appreciate for their careers and work to mean something, as opposed to just as a mean to earn a pay-check or to pass their time (Sverko \& Vizek-Vidovic, 1995).

In this research, the definition of meaningful work looks into not only what work means for individuals, but also how work is helpful in achieving positive valence (Rosso et al., 2010 as cited in Steger et al., 2012). Further, the positive valence of meaning at work is viewed to be growth and purposed-oriented focused (eudaimonic) in contrast to being merely hedonic or pleasure-oriented (Steger et al., 2012). Michaelson (2005) has made a point that organisations have both ethical and moral obligation in supporting employees to have meaningful work, but perhaps a more tangible reason would be that work which is meaningful has shown much advantages for both employees and their organisations. More essentially, meaningful work is said to be significantly correlated with both organisationalrelated and happiness measures (Steger et al., 2012; Arnold et al., 2007). With that, this first hypothesis is derived:

$\mathrm{H}_{1}$ : Meaningful work significantly predicts happiness in the workplace among millennials

\section{Work Autonomy}

This predictor is closely linked to the self-determination theory, which posits that the need to feel autonomous is inherent in us. Work autonomy is defined as an individuals' right or freedom in choosing to partake in things that they find interesting, exciting, and meaningful to them (Gagné \& Bhave, 2011). Much research has been done on work autonomy and it has shown to positively correlate with workplace motivation, productivity, and happiness (Fisher, 2010; Ryan et al., 2013). Autonomy can be present in different aspects in work, and can be categorised further into either job or schedule control. Job control refers to autonomy in relation to the conduct of work and tasks (Karasek, 1989) whereas schedule control refers 
to autonomy with regards to the timing and location of work, and this is often in tandem with work-life balance (Kelly \& Moen, 2007). Greater job and schedule control (work autonomy) is said to yield significant two-fold benefits for employees where it is said to increase job satisfaction, and thus employee happiness (Batt \& Valcour, 2003; De Neve \& Ward, 2017) and also for employers; as autonomous employees are said to have lower turnover intentions (Galletta et al., 2011; Dysvik \& Kuvaas, 2013). However, as there is lack of research on millennials on this subject, hence it is essential to explore if work autonomy does predict happiness at work among this sample. Thus, the second hypothesis is derived:

$\mathrm{H}_{2}$ : Work autonomy significantly predicts happiness in the workplace among millennials

\section{Transformational Leadership}

Transformational leaders are leaders who are able to inspire and raise the interests of their followers, create awareness and upholding of responsibilities, and empower employees to rise above their individualistic goals for the advancement of the group (Seltzer et al., 1989). Also, transformational leadership are said to be individuals who are geared towards change, with an aim to positively influence individual and collective performance (Bass \& Bass, 2008). Many studies have also found significant and positive relationships between transformational leadership and organisational health (Pillai \& Williams, 2004), job satisfaction (Hetland et al., 2007; Abouraia \& Othman, 2017) and significant negative relationships with job-related stress (Sosik \& Godshalk, 2000), and burnout (Hetland et al., 2007). However, as with much of organisational research, there has been minimal research that examines transformational leadership with happiness in the workplace, but instead focuses on relationships with job constructs as outlined above (Nielsen et al., 2008; Jing \& Avery, 2016). With that, this link is worth exploring and the third hypothesis is drawn as follows:

$\mathrm{H}_{3}$ : Transformational leadership significantly predicts happiness in the workplace among millennials

\section{Workplace Friendship}

Workplace friendship can be defined as informal, voluntary and individualcentric communications among employees in the workplace (Berman et al., 2002). Research has shown that workplace friendship is said to hold significant importance in the workplace as it provides support and information exchange (Chen et al., 2012), which consequently aids in job performance (Berman et al., 2002) and 
organisational productivity (Song \& Olshfski, 2008). In a research by Tom Rath (2006) as cited in Fisher (2010), he found that employees who reported that they have had close friends at work, were seven times more probable to experience work engagement. As Fisher (2010) has noted, the literature on social connections in the workplace has been minimal (besides literature on leadership). This is surprising, considering the widely agreed upon thesis that interpersonal relationships are crucial in predicting our happiness (Fisher). Thus, the link between workplace friendship and happiness in the workplace among millennials is crucial and worth exploring and from this, the fourth hypothesis is drawn:

$\mathrm{H}_{4}$ : Workplace friendship significantly predicts happiness in the workplace among millennials

\section{Work-life balance}

The fit between work and personal life or more commonly known as work-life balance has been regarded as a critical work-related factor for employee happiness (Lunau et al., 2014; Amstad et al., 2011). A weak work-life balance is said to be a significant work-related stressor which might then allow for responses arising from stress such as increased blood pressure, cortisol levels, and heart rate (Grzywacz $\&$ Butler, 2008). Studies also show that poor work-life balance is often linked to a range of physical ill health and mental health problems such as depression (Frone, 2000). However, it is also essential to note that work-life balance can differ to demographic, socio-economic, and work and job characteristics (Lunau et al., 2014). For example, countries with effective child care services and generous parental leaves schemes might have a direct influence in the reconciliation of work and everyday life (Lunau et al., 2014). Therefore, with the presumable link between work life balance and happiness in the workplace, the following fifth hypothesis can be derived:

$\mathrm{H}_{5}$ : Work-life balance significantly predicts happiness in the workplace among millennials

\section{Gratitude}

Gratitude is said to be a universal virtue in humans (Emmons, 2007), and is defined as the proactive and conscious practice of being thankful (Howell, 2007 as cited in Waters, 2012). Much research has found moderate to strong positive relationship between gratitude and happiness and also social relationships such as helping behaviours (Wood et al., 2010; Waters, 2012). Nevertheless, taking into account the strong association between gratitude and happiness, there has been 
limited to no research considering this link in an organisational context (Wood et al., 2010; Waters, 2012). In fact, Emmons (2003) has argued that there is no empirical evidence on the utility of gratitude in organisations. Only two research works that exist in the literature on gratitude in an organisational context, with Anderson et al. (2007) finding a significant positive relationship between gratitude and corporate social responsibility and Chan's (2010) research showing a negative relationship between dispositional gratitude and burnout in the workplace among academicians. This presumable relationship between gratitude and happiness is both essential and worthy in extending towards an organisational construct, which thus, derives the sixth hypothesis:

$\mathrm{H}_{6}$ : Gratitude will significantly predict happiness in the workplace among millennials

\section{Underpinning Theory and Proposed Conceptual Framework}

This research serves as an exploratory platform in understanding millennials' happiness in the workplace. To capture the whole picture of happiness at work, the job-related affective well-being construct by Van Katwyk et al. (2000) is adopted. This construct consists of both the affect aspect and one's cognition at work. Specifically, six work-related happiness predictors are being integrated namely meaningful work, work autonomy, transformational leadership, workplace friendship, work life balance, and gratitude. This integration is guided by the selfdetermination theory (SDT) which posits that human motivation and personality are derived from three important psychological needs which are autonomy, competence, and relatedness (Deci \& Ryan, 2000). These three needs are said to be essential and paramount to meet the ideal circumstances for growth and happiness (Deci \& Ryan, 2000) which serves as underlying factors in predicting goal-related and valued outcomes at work. Thus, this research is anchored upon this theory as it allows for us to understand the underlying psychological needs that would need to be met for happiness at work to be attained either in the context of job and organisational characteristics or relationships at work. A full framework of this study is demonstrated in Figure 1 as following. 


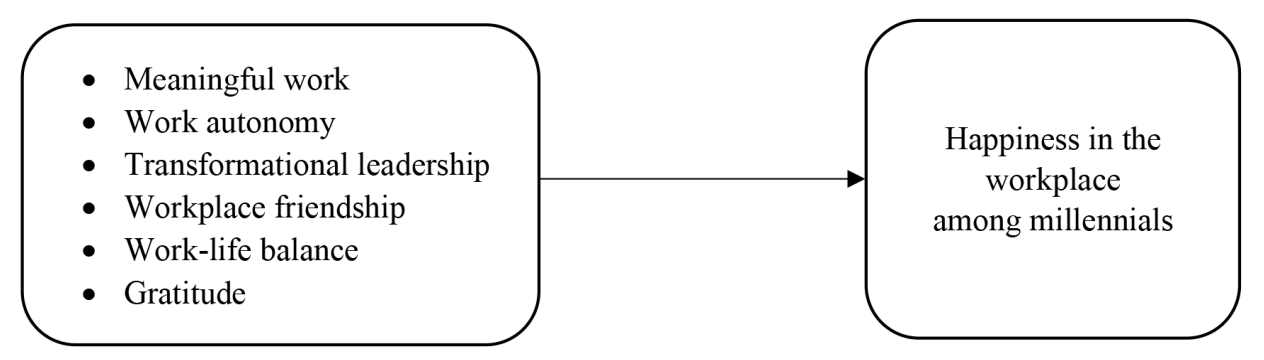

Figure 1. The framework of the study

\section{METHODOLOGY}

\section{Samples and Procedures}

This study consists of Malaysian millennials ("millennials" or Generation Y is defined as individuals born between years 1982 and 2004, according to Howe and Strauss, 2009) who have undergone full time employment of at least one year or more. Selection criteria were individuals aged 20-35 years old and have had or are currently experiencing full time employment of at least one year. Initial pilot test was run to confirm reliability of all instruments. Result from the pilot test suggested that all the instruments satisfied cut-off for Cronbach alpha value of higher than 0.70. A snowball sampling strategy was used with regards to the recruitment of respondents during the real data collection. This strategy was chosen due to its advantage in producing a timely data and being cost effective. An invitation was sent through a link in social media (i.e., Facebook) and emailed to the researchers' own contacts. Those who received the link were encouraged and allowed to circulate the link to their own respective networks. Data collection took place within a period of 2 months and all data were collected through online platforms.

In total, 1005 questionnaires were distributed online and 272 respondents filled and completed the questionnaires, providing the response rate of $27.1 \%$. $64 \%$ of respondents were female whereas $36 \%$ were male. The average or mean age of participants were 27 years old with a standard deviation of 3.2 and participants had an average of 4 years working experience. 


\section{Measures}

The six predictor variables were measured as such; work autonomy was measured with the Work Autonomy Scale (Breaugh, 1999) whereas transformational leadership was measured with the Global Transformational Leadership Scale (Carless et al., 2000). Meaningful work was measured with the Work as Meaning Inventory (Steger et al., 2012). Workplace friendship was measured with the Workplace Friendship Scale (Nielsen et al., 2000). Work-life balance measured with the Work Life Balance scale by Brough et al. (2014). Gratitude was measured with the Gratitude Questionnaire-Six Item Form by McCullough et al. (2002). Lastly, the dependent variable, happiness in the workplace was measured with the Job-related Affective Well-being Scale (JAWS) (Van Katwyk et al., 2000). All the measures have good reliability.

\section{RESULTS}

\section{Descriptive Statistics}

Data analysis was performed using the Statistical Package for the Social Sciences (SPSS). Interestingly, the results indicate that the mean for the JAWS is 95.87 which is lower than the United States' norm working population mean of 105.6 as found by Van Katwyk et al. (2000). Lower mean scores indicate lesser ratings of job-related affective well-being.

\section{Correlation and Coefficients}

Overall, six predictors (workplace friendship, work-life balance, work autonomy, meaning at work, transformational leadership, and gratitude) demonstrated a significant relationship with job-related affective well-being. Specifically, workplace friendship $(r=0.516, p<0.01)$, work-life balance $(r=0.463, p<0.01)$, work autonomy $(r=0.554, p<0.01)$, meaning at work $(r=0.667, p<0.01)$, transformational leadership $(r=0.572, p<0.01)$, gratitude $(r=0.422, p<0.01)$, showed moderate to high positive relationships with job related affective wellbeing. Therefore, this indicates that increasing these six predictors, will increase job related affective well-being.

\section{Regression Analysis}

Table 1 shows the results of the multiple regression analysis of the six respective predictors on JAWS. The results indicate that the six predictors explained $61.9 \%$ 
of the variance in JAWS. Specifically, workplace friendship, $t(272)=3.12, p=$ 0.002 , work-life balance, $t(272)=5.61, p<0.001$, work autonomy, $t(272)=2.80$, $p=0.005$, meaning at work, $t(272)=6.95, p<0.001$, transformational leadership, $t(272)=4.31, p<0.001$; all significantly predicts JAWS. However, gratitude does not significantly predict JAWS, t $(272)=1.38, p>0.05$.

Table 1

Regression analysis - dependent variable: Affective well-being

\begin{tabular}{|c|c|c|c|c|c|c|c|}
\hline \multirow{2}{*}{ Model } & \multirow{2}{*}{$\begin{array}{c}\begin{array}{c}\text { Std. } \\
\text { coefficients }\end{array} \\
\text { Beta }\end{array}$} & \multirow{2}{*}{$t$} & \multirow{2}{*}{ Sig. } & \multicolumn{2}{|c|}{$\begin{array}{l}95.0 \% \text { confidence } \\
\text { interval for B }\end{array}$} & \multicolumn{2}{|c|}{ Collinearity statistics } \\
\hline & & & & $\begin{array}{l}\text { Lower } \\
\text { bound }\end{array}$ & $\begin{array}{l}\text { Upper } \\
\text { bound }\end{array}$ & Tolerance & VIF \\
\hline (Constant) & & 2.353 & 0.019 & 1.917 & 21.579 & & \\
\hline $\begin{array}{l}\text { Workplace } \\
\text { friendship }\end{array}$ & 0.141 & 3.109 & 0.002 & 0.228 & 1.014 & 0.678 & 1.474 \\
\hline $\begin{array}{l}\text { Work-life } \\
\text { balance }\end{array}$ & 0.227 & 5.606 & 0.000 & 0.638 & 1.329 & 0.860 & 1.163 \\
\hline Work autonomy & 0.135 & 2.801 & 0.005 & 0.070 & 0.400 & 0.603 & 1.658 \\
\hline Meaning at work & 0.347 & 6.947 & 0.000 & 0.385 & 0.689 & 0.563 & 1.775 \\
\hline $\begin{array}{l}\text { Transformational } \\
\text { leadership }\end{array}$ & 0.206 & 4.311 & 0.000 & 0.315 & 0.845 & 0.614 & 1.628 \\
\hline Gratitude & 0.061 & 1.382 & 0.168 & -0.089 & 0.509 & 0.732 & 1.366 \\
\hline
\end{tabular}

\section{DISCUSSION}

The results of this study are encouraging with a total of five supported hypotheses with only one hypothesis not supported. Nevertheless, with the regression variance being $61.9 \%$, this shows that the predictors chosen are effective in predicting happiness in the workplace among millennials. Thus, this indicates that the combination of this research's six predictors is able to account for $61.9 \%$ of the variability in scores for job related affective well-being. Meaning at work, transformational leadership, and work-life balance were found to be among the three strongest predictors in this study. Firstly, this means that increasing meaning at work will consequently increase millennials' happiness at work. This is supported by the Job Characteristics Model which discusses on the experienced meaningfulness of work as one of the three essential psychological states as positive reinforcers at work (Richard \& Oldham, 1976). 
This result is consistent with past studies by Steger at al. (2012) and Arnold et al. (2007), even considering the narrowed sample of millennials in this research. This finding is of paramount importance as research has been minimal to none on meaningful work among millennials. In fact, most findings on millennials' perception on meaningful work are based on large surveys conducted by consulting firms or articles written (Heathfield, 2017) which are often opinion and not research based. In an article written by Vesty (2016), she stated that millennials with minimal work experience will focus more on establishing financial independence based on a large scale survey conducted by Imperative, and as people age, only then would they think about prioritising meaning at work. Clearly, the results of this research argue against this, as for participants in this research having only an average of four years of working experience, meaningful work is the strongest predictor of happiness in the workplace.

Transformational leadership was also found to be of the three most significant predictors of happiness in the workplace among millennials. A reason for this could be that millennials are said to be employees who are driven by leaders who inspire others, and would be in an organisation that serves to create a positive impact in society (Brousell, 2015). With that, a transformational leader will then act as a role model for the followers (idealised influence), which will presumably inspire their followers to learn and grow both professionally and personally; consequently, enhancing happiness in the workplace. This might provide a generational management gap as boomers are said to embody a more rigid leadership style which are more autocratic and focused on command and control (Brousell, 2015). Nevertheless, as the oldest millennials are now 35 years old (Williams, 2015), many of them are instead, offered opportunities to be managers or leaders as a form of succession planning. However, studies have shown that millennials might be hesitant to take on such leadership roles as this could affect their treasured work-life balance (Morgan, 2015). Instead, millennials might use transformational leadership to create strong collaboration and teaming skills (by using inspiration and bringing out the best in teammates) to share this additional workload demands (Morgan, 2015).

In addition, work-life balance is also found to be one of the three most significant predictors of happiness in the workplace among millennials. This finding could be explained by millennials being a free-spirited, socially focused generation, and gravitating towards a work to live perspective (Kroth \& Young, 2014). Nevertheless, this could pose as a management challenge as in contrast, boomers are believed to adopt a live to work perspective (Gursoy et al., 2008). Thus, more research needs to be done to address this generational and subsequent management gap. Another reason could be due to an observation made by Hershatter and Epstein (2010) who 
argued that millennials are more family centric as they have seen first-hand their boomer parents' sacrifices in achieving corporate success. This had made them experience a lack in family time, and spending long days in childcare or aftercare programs (Hershatter \& Epstein, 2010). With that, millennials are said to enter the work force appreciating a higher level of work-life balance.

It was also discovered that work autonomy is a significant predictor of happiness in the workplace and this is consistent with past studies (McGonagle, 2015; Warr, 2007), even with a sample of millennials. However, as McGonagle (2015) accurately notes; working autonomously should not be an individualistic and independent effort, but a working style that is able to contribute positively to the work ecosystem. Perhaps, a reason why work autonomy holds significance for millennials is that by allowing autonomy in the job, millennials feel that this would allow them certain levels of freedom to be innovative and creative in the workplace (Holt et al., 2012). Another reason could be that the extensive use of technology has blurred the lines of where, when and how millennials do work (job and schedule control), which makes rigid hierarchies and outdated management styles not preferred by millennials (PricewaterhouseCoopers, 2011).

Besides, workplace friendship is a significant predictor of happiness in the workplace among millennials, lending support to the thesis that interpersonal relationships are crucial in predicting our happiness and well-being (Fisher, 2010). In a survey done by LinkedIn through a sample of 11,500 full-time professional, it was found that $57 \%$ of millennials reported that positive work relationships make them feel happier and $50 \%$ said that this would make them feel more motivated at work (Fisher, 2014). It was also found that $67 \%$ of millennials were more likely to share their personal details such as family or relationships issues with their co-workers as compared to approximately one third of baby boomers (Fisher, 2014). Clearly, there is a generational gap and this is perhaps due to the fact that millennials who are still single might view work relationships as an extension of their own family whereas boomers with their own family might view work friendships as merely transactional. Future research could look into the marital status of millennials to ascertain if it has an effect on their perception towards workplace friendship.

Lastly, gratitude is found to have a strong correlation with happiness in the workplace but however, it is found to be not significant in the regression analysis. Therefore, it is argued that gratitude is only correlated with happiness in the workplace but does not significantly impact it at least not among a sample of millennials in an organisational context. A possible reason for this result is that the gratitude questionnaire used in this study is constructed with a focus on gratitude towards life in general (as opposed to work context), and this thus, is not significantly 
linked with the dependent variable which measures happiness only with regards to one's workplace. Also, there is emerging literature that has looked into the variable of institutionalised gratitude which defined gratitude as embedded culturally in an organisation through its respective policies and operational procedures, which allows for appreciation and thankfulness to be a norm in everyday work life (Cameron, 2012). With that, as opposed to an individual's dispositional gratitude, the variable of institutionalised gratitude is fostered through and in organisations which looks at the impact of gratitude outside of the individual (Waters, 2012). Thus, although this research has shown no significance for dispositional gratitude, this does not mean that cultivating gratitude in the workplace for employee happiness is not effective; but perhaps operationally defining gratitude to be measured specifically in the work place context would be more useful.

\section{CONCLUSION AND RECOMMENDATION}

This research has found that meaning at work, transformational leadership, worklife balance, work autonomy, and workplace friendship were significant predictors of workplace happiness. Firstly, this posits the importance of organisations to advance a sense of meaning at work through possible ways such as ensuring employees work-role fit, corporate social responsibility, and task significance. Further, future research should look at developing ways to create a sense of meaning at work and subsequently validating its efficacy and utility among millennials. With regards to transformational leadership, it is also imperative for future research to be focused on ways in which millennials lead, as they are not just increasingly dominating the workforce but also taking on leadership roles. This is crucial as just because millennials prefer to be led by a transformational leader, this does not mean that they themselves will lead in the same manner. On work autonomy, future research could look into how organisations are able to execute and implement work autonomy in a respective job. A practical suggestion would be to focus on the results of work, as opposed to the procedural nature of work such as time and location which thus, gives way and promotes for work autonomy. Lastly, although this research has shown that workplace friendship predicts happiness in the workplace among millennials, future research could also look into the influence of other variables such as competitions for work promotion on work friendships. This is because when millennials were asked whether they would sacrifice friendship over a promotion, $68 \%$ of millennials said they would, which is contrast to the $62 \%$ of baby boomers who reported that they would not (Fisher, 2014). 
With this research, it is hoped that there is greater awareness on ways to improve happiness at work which will allow for overall better work productivity and performance, and the retention of millennial talent in organisations. This is essential as a happy employee is said to be a competitive edge for organisations, as they are more probable in engaging with proactive behaviour, are efficient, motivated and aligned with organisational goals (Achor, 2010). As elderly employees are gradually retiring and millennials set to make up $50 \%$ of the entire workforce by 2020 (Deal et al., 2011), the burden will fall towards organisations to not only understand generational differences and millennials in the workplace, but to develop the best ways in managing them. Organisations which are agile, and ready for millennials to reshape the workplace would be the ones in which would prevail and succeed as we enter the fourth industrial revolution (Schwab, 2017).

\section{ACKNOWLEDGEMENT}

This study received ethic approval and was supported by the University of Nottingham.

\section{REFERENCES}

Abouraia, M.K., \& Othman, S.M. (2017). Transformational leadership, job satisfaction, organizational commitment, and turnover intentions: The direct effects among bank representatives. American Journal of Industrial and Business Management, 7(4), 404-423. https://doi.org/10.4236/ajibm.2017.74029

Achor, S. (2010). The happiness advantage: The seven principles that fuel success and performance at work. Virgin Books.

Allvin, M., Aronsson, G., Hagström, T., Johansson, G., \& Lundberg, U. (2011). Work without boundaries: Psychological perspectives on the new working life. Wiley. https://doi.org/10.1002/9781119991236

Amstad, F.T., Meier, L.L., Fasel, U., Elfering, A., \& Semmer, N.K. (2011). A metaanalysis of work-family conflict and various outcomes with a special emphasis on cross-domain versus matching-domain relations. Journal of Occupational Health Psychology, 16(2), 151-169. https://doi.org/10.1037/a0022170

Anderson, L.M., Giacalone, R.A., \& Jurkiewicz, C.L. (2007). On the relationship of hope and gratitude to corporate social responsibility. Journal of Business Ethics, 70, 401-409. https://doi.org/10.1007/s10551-006-9118-1

Arnold, K.A., Turner, N., Barling, J., Kelloway, E.K., \& McKee, M.C. (2007). Transformational leadership and psychological well-being: The mediating role of meaningful work. Journal of Occupational Health Psychology, 12, 193-203. https://doi.org/10.1037/1076-8998.12.3.193 
Baas, M., De Dreu, C.K.W., \& Nijstad, B.A. (2008). A meta-analysis of 25 years of moodcreativity research: Hedonic tone, activation, or regulatory focus. Psychological Bulletin, 134, 779-806. https://doi.org/10.1037/a0012815

Bakker, A.B., Schaufeli, W.B., Leiter, M.P., \& Taris, T.W. (2008). Work engagement: An emerging concept in occupational health psychology. Work \& Stress, 22(3), 187-200. https://doi.org/10.1080/02678370802393649

Bass, B.M., \& Bass, R. (2008). The Bass handbook of leadership: Theory, research, \& managerial applications (4th ed.). Free Press.

Batt, R., \& Valcour, P.M. (2003). Human resources practices as predictors of work-family outcomes and employee turnover. Industrial Relations, 42(2), 189-220. https:// doi.org/10.1111/1468-232x.00287

Berman, E.M., West, J.P., \& Richter, M.N. (2002). Workplace relations: Friendship patterns and consequences (according to managers). Public Administration Review, 62, 217-230. https://doi.org/10.1111/0033-3352.00172

Breaugh, J. (1999). Further investigation of the Work Autonomy Scales: Two studies. Journal of Business and Psychology, 13(3), 357-373.

Brief, A.P. (1998). Attitudes in and around organizations. SAGE.

Briner, R.B. (1997, January). Beyond stress and satisfaction: Understanding and managing emotions at work. Paper presented at the Occupational Psychology Conference, Blackpool.

Brough, P., Timms, C., O’Driscoll, M.P., Kalliath, T.J., Siu, O.L., Sit, C., \& Lo, D. (2014). Work-life balance: A longitudinal evaluation of a new measure across Australia and New Zealand workers. The International Journal of Human Resource Management, 25, 2724-2744. https://doi.org/10.1080/09585192.2014.899262

Brousell, L. (2015, August 4). How millennials challenge traditional leadership. https:// www.cio.com/article/2956600/leadership-management/how-millennialschallenge-traditional-leadership.html

Cameron, K. (2012). Effects of virtuous leadership of organizational performance. In S.I. Donaldson, M. Csikszentmihlyi., \& J. Nakamura (Eds.), Applied positive psychology: Improving everyday life, health, schools, work and Society (pp. 171183). Routledge. https://doi.org/10.4324/9780203818909

Carless, S., Wearing, A., \& Mann, A. (2000). A short measure of transformational leadership. Journal of Business and Psychology, 14(3), 389-405.

Chan, D. (2010). Gratitude, gratitude intervention and subjective well-being among Chinese school teachers in Hong Kong. Educational Psychology, 30, 139-153. https://doi.org/10.1080/01443410903493934

Chen, C., Mao, H., \& Hsieh, A. (2012). Role ambiguity, employee gender, and workplace friendship. Psychological Reports, 110(3), 719-730. https://doi. org/10.2466/01.07.21.pr0.110.3.719-730

Deal, J., Altman, J., \& Rogelberg, D. (2010). Millennials at work: What we know and what we need to do (if anything). Journal of Business and Psychology, 25(2), 191-199. https://doi.org/10.1007/s10869-010-9177-2

Deal, J., Altman, J., \& Rogelberg, D. (2011). Erratum to: Millennials at work: What we know and what we need to do (if anything). Journal of Business and Psychology, 26(1), 123. https://doi.org/10.1007/s10869-010-9208-z 
Deci, E.L., \& Ryan, R.M. (2000). The "what" and "why" of goal pursuits: Human needs and the self-determination of behavior. Psychological Inquiry, 11(4), 227-268. https://doi.org/10.1207/s15327965pli1104_01

Deloitte, T. (2014). Big demands and high expectations: The Deloitte millennial survey. https://www2.deloitte.com/content/dam/Deloitte/global/Documents/AboutDeloitte/gx-dttl-2014-millennial-survey-report.pdf. https://doi.org/10.1093/ww/ 9780199540884.013.u45187

De Neve, J.E., \& Ward, G. (2017). Happiness at work. Saïd Business School WP, 1 February. https://doi.org/10.2139/ssrn.2943318

Diener, E. (2000). Subjective well-being. American Psychologist, 55, 34-43.

Diener, E., Thapa, S., \& Tay, L. (2019). Positive emotions at work. Annual Review of Organizational Psychology and Organizational Behavior, 7, 451-477. https:// doi.org/10.1146/annurev-orgpsych-012119-044908

Dysvik, A., \& Kuvaas, B. (2013). Perceived job autonomy and turnover intention: The moderating role of perceived supervisor support. European Journal of Work and Organizational Psychology, 22(5), 563-573. https://doi.org/10.1080/135943 2x.2012.667215

Emmons, R. (2003). Acts of gratitude in organizations. In K.S. Cameron, J.E. Dutton, \& R.E. Quinn (Eds.), Positive organizational scholarship (pp. 81-93). BerrettKoehler.

Emmons, R.A. (2007). Thanks! How the new science of gratitude can make you happier. Houghton-Mifflin.

Fisher, C.D. (2010). Happiness at work. International Journal of Management Reviews, 12(4), 384-412.

Fisher, C. (2014). LinkedIn study reveals work BFFs make us happier at the office. https:// blog.linkedin.com/2014/07/08/work-bffs.

Frone, M.R. (2000). Work-family conflict and employee psychiatric disorders: The national comorbidity survey. Journal of Applied Psychology, 85(6), 888-895. https://doi. org/10.1037/0021-9010.85.6.888

Gagné, M., \& Bhave, D. (2011). Autonomy in the workplace: An essential ingredient to employee engagement and well-being in every culture. In V.I. Chirkov, R.M. Ryan, \& K.M. Sheldon (Eds.), Human autonomy in cross-cultural context (pp. 163-187). Springer. https://doi.org/10.1007/978-90-481-9667-8_8

Galletta, M., Portoghese, I., \& Battistelli, A. (2011). Intrinsic motivation, job autonomy and turnover intention in the Italian healthcare: The mediating role of affective commitment. Journal of Management Research, 3(2), 1-19. https://doi. org/10.5296/jmr.v3i2.619

Gallup. (2012). Gallup engagement index. http://eu.gallup.com/berlin/118645/gallupengagement-index.aspx. https://doi.org/10.7312/ohme12132-015

Grzywacz, J.G., \& Butler, A.B. (2008). Work-family conflict. In J. Barling, \& C.L. Cooper (Eds.), The SAGE handbook of organizational behavior (pp. 451-468). SAGE. https://doi.org/10.4135/9781849200448.n25 
Gursoy, D., Maier, T., \& Chi, C. (2008). Generational differences: An examination of work values and generational gaps in the hospitality workforce. International Journal of Hospitality Management, 27(3), 448-458. https://doi.org/10.1016/ j.ijhm.2007.11.002

Harter, J.K., Schmidt, F.L., \& Hayes, T.L. (2002). Business unit-level relationship between employee satisfaction, employee engagement, and business outcomes: A metaanalysis. Journal of Applied Psychology, 87, 268-279. https://doi. org/10.1037/0021-9010.87.2.268

Heathfield, S. (2017, November 8). 11 tips for managing millennials. https:/www. thebalance.com/tips-for-managing-millennials-1918678.

Hershatter, A., \& Epstein, M. (2010). Millennials and the world of work: An organization and management perspective. Journal of Business and Psychology, 25(2), 211223. https://doi.org/10.1007/s10869-010-9160-y

Hetland, H., Sandal, G.M. \& Johnsen, T.B. (2007) Burnout in the information technology sector: Does leadership matter? European Journal of Work and Organizational Psychology, 16, 58-75.

Hira, N. (2007). You raised them, now manage them. Fortune, 28 May.

Holt, S., Marques, J., \& Way, D. (2012). Bracing for the millennial workforce: Looking for ways to inspire Generation Y. Journal of Leadership, Accountability and Ethics, 9(6), 81-93.

Howe, N., \& Strauss, W. (2009). Millennials rising: The next great generation. Vintage.

Jacobson, W.S. (2007). Two's company, three's a crow, and four's a lot to manage: Supervising in today's intergenerational workplace. Popular Government, 17, $18-23$.

Jing, F.F., \& Avery, G.C. (2016). Missing links in understanding the relationship between leadership and organizational performance. International Business \& Economics Research Journal (IBER), 15(3), 107-118. https://doi.org/10.19030/iber. v15i3.9675

Joshanloo, M. et al. (2016). Conceptions of happiness and life satisfaction: An exploratory study in 14 national groups. Personality and Individual Differences, 102, 145148.

Karasek, R. (1989). Control in the workplace and its health-related aspects. In S.L. Sauter, J.J. Hurrell, \& C.L. Cooper (Eds.), Job control and worker health (pp. 129-160). Wiley.

Kelly, E., \& Moen, P. (2007). Rethinking the clockwork of work: Why schedule control may pay off at work and at home. Advances in Developing Human Resources, 9(4), 487-506. https://doi.org/10.1177/1523422307305489

Kelly Services. (2009). Kelly global workforce index: February 2009. https://issuu.com/ michaelkirsten/docs/kelly_global_workforce_index_2009.

Kroth, A., \& Young, S.J. (2014). New professionals, new desires: What millennials want in their work. Recreational Sports Journal, 38(1), 23-32.

Lunau, T., Bambra, C., Eikemo, T.A., van Der Wel, K.A., \& Dragano, N. (2014). A balancing act? Work-life balance, health and well-being in European welfare states. The European Journal of Public Health, 24(3), 422-427. https://doi. org/10.1093/eurpub/cku010 
ManpowerGroup (2016). Millennial careers: 2020 vision. https://www.manpower.ch/sites/ default/files/PDF/Y_Generation_Bro_Manpower_Switzerland_EN_June2016. pdf

McCullough, M.E., Emmons, R.A., \& Tsang, J. (2002). The grateful disposition: A conceptual and empirical topography. Journal of Personality and Social Psychology, 82, 112-127. https://doi.org/10.1037/0022-3514.82.1.112

McGonagle, C. (2015). Happiness in the workplace: An appreciative inquiry [Doctoral dissertation, Dublin City University].

Michaelson, C. (2005). "I want your shower time!': Drowning in work and the erosion of life. Business and Professional Ethics Journal, 24, 7-26. https://doi.org/10.5840/ bpej200524417

Morgan, H. (2015, July 22). What kind of leaders are millennials? https://money.usnews. com/money/blogs/outside-voices-careers/2015/07/22/what-kind-of-leaders-aremillennials.

Myers, K.K., \& Sadaghiani, K. (2010). Millennials in the workplace: A communication perspective on Millennials' organizational relationships and performance. Journal of Business and Psychology, 25, 225-238. https://doi.org/10.1007/s10869-0109172-7

Nielsen, I.K., Jex, S.M., \& Adams, G.A. (2000). Development and validation of scores on a two-dimensional workplace friendship scale. Educational and Psychological Measurement, 60(4), 628-643.

Nielsen, K., Yarker, J., Brenner, S., Randall, R., \& Borg, V. (2008). The importance of transformational leadership style for the well-being of employees working with older people. Journal of Advanced Nursing, 63(5), 465-475. https://doi. org/10.1177/00131640021970655

Pillai, R., \& Williams, E. (2004). Transformational leadership, self-efficacy, group cohesiveness, commitment, and performance. Journal of Organizational Change Management 17, 144-159. https://doi.org/10.1108/09534810410530584

PricewaterhouseCoopers. (2011). Millennials at work: Reshaping the workplace. http:// www. pwc.ru/en_RU/ru/hr-consulting/publications/assets/millenials-survey. pdf

Richard, H.J., \& Oldham, G. (1976). Motivation through the design of work: Test of a theory. Organizational Behavior and Human Performance, 16(2), 250-279. https://doi.org/10.1016/0030-5073(76)90016-7

Ryan, R.M., Huta, V., \& Deci, E.L. (2013). Living well: A self-determination theory perspective on eudaimonia. In A.D. Fave (Ed.), The exploration of happiness (pp. 117-139). Springer Netherlands. https://doi.org/10.1007/978-94-007-5702-8_7

Sverko, B., \& Vizek-Vidovic, V. (1995). Studies of the meaning of work: Approaches, models, and some of the findings. In D. E. Super \& B. Sverko (Eds.), Life roles, values, and careers (pp. 3-21). Jossey-Bass.

Salanova, M., Bakker, A.B., \& Llorens, S. (2006). Flow at work: Evidence for an upward spiral of personal and organizational resources. Journal of Happiness Studies, 7, 1-22. https://doi.org/10.1007/s10902-005-8854-8

Schwab, K. (2017). The fourth industrial revolution. Crown Business. 
Seltzer J., Numerof, R., \& Bass, B. (1989). Transformational leadership: Is it a source of more burnout and stress? Journal of Health and Human Resources Administration 12, 174-185.

Song, S.H., \& Olshfski, D. (2008). Friends at work: A comparative study of work attitudes in Seoul city government and New Jersey state government. Administration \& Society, 40, 147-169. https://doi.org/10.1177/0095399707312827

Sosik, J., \& Godshalk, V. (2000). Leadership styles, mentoring functions received, and job-related stress: A conceptual model and preliminary study. Journal of Organizational Behavior, 21, 365-390.

Steger, M.F., Dik, B.J., \& Duffy, R.D. (2012). Measuring meaningful work: The work and meaning inventory (WAMI). Journal of Career Assessment, 20(3), 322-337. https://doi.org/10.1177/1069072711436160

Stride, C., Wall, T.D., \& Catley, N. (2008). Measures of job satisfaction, organisational commitment, mental health and job related well-being: A benchmarking manual. John Wiley \& Sons. https://doi.org/10.1111/j.1744-6570.2009.01143_7.x

Van Katwyk, P.T., Fox, S., Spector, P.E., \& Kelloway, E.K. (2000). Using the Job-related Affective Well-being Scale (JAWS) to investigate affective responses to work stressors. Journal of occupational health psychology, 5(2), 219-230. https://doi. org/10.1037/1076-8998.5.2.219

Vesty, L. (2016). Millennials want purpose over paychecks. So why can't we find it at work? https:/www.theguardian.com/sustainable-business/2016/sep/14/millennialswork-purpose-linkedin-survey.

Warr, P. (1990). The measurement of well-being and other aspects of mental health. Journal of Occupational and Organizational Psychology, 63(3), 193-210.

Warr, P. (2007). Work, happiness and unhappiness. Laurence Erlbaum Associates.

Waters, L. (2012). Predicting job satisfaction: Contributions of individual gratitude and institutionalized gratitude. Psychology, 3(12), 1174-1176. https://doi. org/10.4236/psych.2012.312a173

Williams, A. (2015, 20 September). Move over, millennials, here comes Generation Z. The New York Times. https://www.nytimes.com/2015/09/20/fashion/move-overmillennials-here-comes-generation-z.html. https://doi.org/10.2307/3961660

Wood, A., Froh, J., \& Geraghty, A. (2010). Gratitude and well-being: A review and theoretical integration. Clinical Psychology Review, 30, 890-905. https://doi. org/10.1016/j.cpr.2010.03.005 